\title{
SNP 1772 C > T of HIF-1a gene associates with breast cancer risk in a Taiwanese population
}

\author{
Chih-Jen Huang ${ }^{1,2+}$, Shi-Long Lian ${ }^{1,2+}$, Ming-Feng Hou ${ }^{3,4,5}$, Chee-Yin Chai ${ }^{6,7,8}$, Yi-Hsing Yang ${ }^{9}$, Sheng-Fung Lin ${ }^{10^{*}}$ \\ and Hsueh-Wei Chang $5,11,12,13^{*}$
}

\begin{abstract}
Background: Hypoxia inducible factor $1 \mathrm{a}(\mathrm{HIF-1a)}$ is a stress-responsive transcription factor to hypoxia and its expression is correlated to tumor progression and angiogenesis. Several single nucleotide polymorphisms (SNPs) of HIF-1a gene in the oxygen-dependent degradation (ODD) domain was reportedly associated with increased HIF-1a activity.

Results: In this study, we focused on the relationship between SNP 1772 C > T (rs11549465) of HIF-1a gene and its breast cancer risk, as well as its correlation with HIF-1a expression and tumor angiogenesis. Ninety six breast cancer patients and 120 age-matched controls were enrolled. We found that $1772 \mathrm{~T}$ allele of HIF-1a gene was associated with increased breast cancer risk (adjusted $\mathrm{OR}=14.51 ; 95 \% \mathrm{Cl}$ : 6.74-31.24). This SNP was not associated with clinicopathologic features of angiogenesis such as VEGF activity and the micro-vessel density and survival of breast cancer patients.
\end{abstract}

Conclusion: Taken together, the 1772 C > T of HIF-1a gene is a potential biomarker for breast cancer susceptibility.

Keywords: HIF-1a, SNPs, Breast cancer, Association study, Survival

\section{Background}

Single nucleotide polymorphisms (SNPs), the most common variants in human genome [1], are popular biomarkers for disease/cancer prediction and therapeutic evaluation [2-8]. Most SNPs have been reported to be associated with breast cancer [9-11], however, other SNPs are still potential to be associated with breast cancer.

Tumor hypoxia is common in tumorigenesis. Hypoxia inducible factor-1 (HIF-1) is a crucial transcription factor in cellular response to tumor hypoxia and is considered as an adverse prognostic factor in breast cancers [12-14]. Additionally, the HIF- $1 \alpha$ isoform is the oxygenregulated component that controls HIF-1 activity [15]. The degradation of HIF- $1 \alpha$ depends on prolyl hydroxylation. Under normoxic status, oxygen-dependent prolyl hydroxylases $[16,17]$ may hydroxylate the HIF- $1 \alpha$ on proline

\footnotetext{
* Correspondence: shlin@kmu.edu.tw; changhw@kmu.edu.tw

${ }^{\dagger}$ Equal contributors

${ }^{10}$ Department of Medical Oncology, Kaohsiung Medical University Hospital, Kaohsiung Medical University, Kaohsiung, Taiwan

${ }^{5}$ Cancer Center, Kaohsiung Medical University Hospital, Kaohsiung Medical University, Kaohsiung, Taiwan

Full list of author information is available at the end of the article
}

residues 402 and 564 located in the oxygen-sensitive degradation domain (ODD, encoded by codons 401-603) of HIF- $1 \alpha$. In contrast, degradation of HIF- $1 \alpha$ is suppressed under hypoxic status. Therefore, the SNPs located at several proline residues of HIF- $1 \alpha$ gene in breast cancer association are potential to modulate the HIF- $1 \alpha$ activity.

Recent studies demonstrated that another SNP located

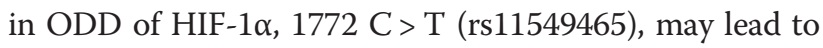
an amino acid change from proline 582 to serine (P582S) and are reportedly associated with renal $[18,19]$, head and neck [20], prostate [21], lung [22], and pancreatic [23] cancers. Meta-analysis from 34 case-control studies also reported that SNP $1772 \mathrm{C}>\mathrm{T}$ (P582S) of HIF-1 $\alpha$ gene is significantly associated with breast cancer risk in many countries [24]. However, the association of SNP 1772 C > $\mathrm{T}$ (rs11549465) of the HIF- $1 \alpha$ gene to breast cancer remains unclear in a Taiwanese population.

The purpose of this study is to investigate the association between SNP $1772 \mathrm{C}>\mathrm{T}$ of the HIF-1 $\alpha$ gene in breast cancer patients and healthy control subjects. Furthermore, HIF-1 has been reported to transactivate many oxygen responsive genes such as vascular endothelial growth factor (VEGF) [25]. Therefore, the relationships 
between genotypes of SNP $1772 \mathrm{C}>\mathrm{T}$ of HIF-1 $\alpha$ gene and the clinicopathologic characteristics, the immunostaining expression levels of HIF- $1 \alpha$ and VEGF, and clinical outcomes of breast cancer are also addressed in this study.

\section{Methods and materials}

Patient characteristics and control subjects

Between 1991 and 2001, a total of 96 randomly-selected female patients with breast cancer at Kaohsiung Medical University Hospital, Kaohsiung, Taiwan, were enrolled in this study. All patients underwent a standard modified radical mastectomy. Ninety-four patients (94/96, 98\%) received adjuvant systemic chemotherapy with 6 cycles of 5-fluorourcil, doxorubicin and cyclophosphamide. After completion of chemotherapy, all patients received hormone therapy with tamoxifen and 92 patients (92/96, 96\%) received radiation therapy. The principle of treatment was followed as described previously [26]. We collected clinical data including clinical stage, treatment outcomes and follow-up status. Controls were recruited from 120 healthy female without a history of cancer and matched to the breast cancer patients by sex and age.

\section{DNA extraction and PCR-RFLP}

Genomic DNA was isolated from paraffin-embedded tumor tissues of surgical specimens and peripheral blood of 120 normal controls as described [27,28]. The sequence of primers for HIF- $1 \alpha$ is as follows: forward 5 -AGGACA CAGATTTAGACTTGG-3' and reverse 5'-GGAATACT GTAACTGTGCTTTG-3'. PCR reaction mixture $(10 \mu \mathrm{l})$ contained $1 \mu \mathrm{l}$ of $10 \times$ PCR buffer, $0.3 \mu \mathrm{l}$ of $50 \mathrm{mM} \mathrm{MgCl}_{2}$, $0.2 \mu \mathrm{l}$ of $10 \mathrm{mM}$ dNTP each, $0.6 \mu \mathrm{l}$ DMSO, $0.14 \mu \mathrm{l}$ of Taq enzyme, $0.12 \mu \mathrm{l}$ of $350 \mu \mathrm{g} / \mathrm{ml}$ primers mix (1:1), $2 \mu \mathrm{l}$ DNA extracts and $5.64 \mu \mathrm{l}$ distilled water. PCR was performed with the following protocol: $94^{\circ} \mathrm{C}(1 \mathrm{~min}) ; 4$ cycles of $94^{\circ} \mathrm{C}$ (15 s), $64^{\circ} \mathrm{C}(15 \mathrm{~s}), 70^{\circ} \mathrm{C}(8 \mathrm{~s}) ; 4$ cycles of $94^{\circ} \mathrm{C}(15 \mathrm{~s}), 61^{\circ} \mathrm{C}$
(15 s), $70^{\circ} \mathrm{C}(8 \mathrm{~s}) ; 4$ cycles of $94^{\circ} \mathrm{C}(15 \mathrm{~s}), 58^{\circ} \mathrm{C}(15 \mathrm{~s}), 70^{\circ} \mathrm{C}$ $(8 \mathrm{~s}) ; 60$ cycles of $94^{\circ} \mathrm{C}$ for $(15 \mathrm{~s}), 55^{\circ} \mathrm{C}(15 \mathrm{~s}), 70^{\circ} \mathrm{C}(8 \mathrm{~s})$; $94^{\circ} \mathrm{C}(1 \mathrm{~min})$ and $60^{\circ} \mathrm{C}(5 \mathrm{~min})$. The available restriction enzyme for HIF-1 $\alpha 1772 \mathrm{C}>\mathrm{T}$ (rs11549465) was retrieved from the SNP-RFLP freeware [29-31]. PCR products were digested with the $\mathrm{Hph} I$ restriction enzyme (NEB) at $37^{\circ} \mathrm{C}$ for overnight and then they were subjected to 3\% agarose electrophoresis and stained with SYBR Safe ${ }^{\mathrm{Tm}}$ DNA gel stain (Invitrogen) for visualization of the PCR-restriction fragment length polymorphism (PCR-RFLP) patterns.

\section{Sequencing}

Typical patterns of genotyping by PCR-RFLP have confirmed by sequencing. DNA amplicon from PCR reaction was purified using a MiniElute PCR purification kit (Qiagen) [28] for commercial sequencing.

Immunohistochemical analyses of HIF-1a and VEGF proteins Streptoavidin-biotin based immunohistochemical staining (IHC) was performed to detect HIF- $1 \alpha$ and VEGF protein levels as previously described [32]. Immunoreactivity of HIF- $1 \alpha$ was located in both nuclei and cytoplasm. Using a semiquantitative scale described previously [33], the HIF- $1 \alpha$ expression were classified as follows: $1+$, nuclear staining in less than $1 \%$ of cells; $2+$, nuclear staining in $1-10 \%$ of cells and/or with weak cytoplasmic staining; $3+$, nuclear staining in $10-50 \%$ of cells and/or with distinct cytoplasmic staining; 4+, nuclear staining in more than $50 \%$ of cells and/or with strong cytoplasmic staining. For further analysis, we defined two groups of low and high HIF- $1 \alpha$ expression: $1+$ or $2+$ staining pattern regarded as low expression, and $3+$ or $4+$ staining pattern as high expression. VEGF expression was assessed according to the intensity of cytoplasmic staining as described previously [32]. VEGF expression was detected tumor cells in a distinct and strongly cytoplasmic staining. VEGF staining was defined as four grades as follows: no staining, weak,

Table 1 HIF-1a 1772 C > T genotype and allele frequencies in breast cancer patients and control subjects

\begin{tabular}{|c|c|c|c|c|c|c|c|}
\hline Parameters & Breast cancer patients & Control subjects & $p$ value $^{a}$ & Crude OR & Adjusted $O R^{b}$ & $p$ value & $95 \% \mathrm{Cl}$ \\
\hline Age & $46.5 \pm 9.9(19-73)$ & $44.6 \pm 11.5(21-77)$ & 0.224 & & & & \\
\hline CC (\%) & $53(55 \%)$ & $116(97 \%)$ & & 1.00 & 1.00 & & \\
\hline CT (\%) & $21(22 \%)$ & $0(0 \%)$ & & & & & \\
\hline Tा (\%) & $22(23 \%)$ & $4(3 \%)$ & $<0.001$ & 12.04 & 11.33 & $<0.001$ & $3.70-34.72$ \\
\hline CT/CC (\%) & $74(77 \%)$ & $116(97 \%)$ & & 1.00 & 1.00 & & \\
\hline Tा (\%) & $22(23 \%)$ & $4(3 \%)$ & $<0.001$ & 8.62 & 8.31 & $<0.001$ & $2.74-25.25$ \\
\hline CC (\%) & $53(55 \%)$ & $116(97 \%)$ & & 1.00 & 1.00 & & \\
\hline СТ/ТT (\%) & $43(45 \%)$ & $4(3 \%)$ & $<0.001$ & 23.53 & 23.23 & $<0.001$ & $7.92-68.09$ \\
\hline C genotype (\%) & $127(66 \%)$ & $232(97 \%)$ & & 1.00 & 1.00 & & \\
\hline T genotype (\%) & $65(34 \%)$ & $8(3 \%)$ & $<0.001$ & 14.84 & 14.51 & $<0.001$ & $6.74-31.24$ \\
\hline
\end{tabular}

Comparisons were performed by Chi-Square test.

${ }^{\mathrm{b}}$ Adjusted by age by conditional logistic regression analysis.

$O R=$ odds ratio; $\mathrm{Cl}=$ Confidence interval. 


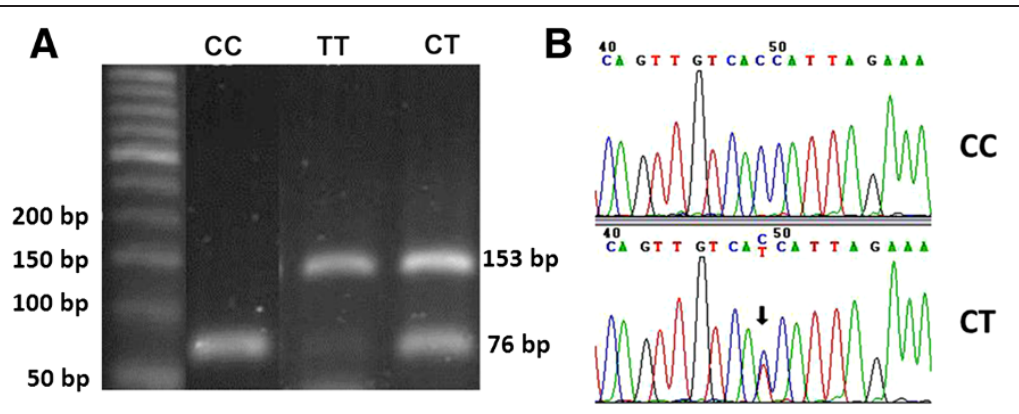

Figure 1 PCR-RFLP genotyping and sequencing of SNP 1772 C > T of HIF-1a gene. (A) PCR-RFLP genotyping of SNP 1772 C > T of HIF-1a gene (76 bp, C-allele; 153 bp, T-allele) in formalin-fixed, paraffin-embedded breast cancer tissues. (B) Sequence chromatograms of PCR-RFLP product contained SNP 1772 C > T of HIF-1a gene. Arrow indicated location of 1772 C > T.

distinct and strong cytoplasmic staining. Distinct and strong cytoplasmic staining was defined as high VEGF and negative or weak cytoplasmic staining was defined as low VEGF expression.

\section{Immunohistochemical analysis for microvessel detection}

Microvessel density (MVD) represents tumor angiogenesis by using immunostaining of endothelial cells with monocloncal antibody, recognizing the CD31 endothelial glycoprotein. Each slide was scanned at low magnification $(\times 100)$ to identify the four areas of high density of microvessels (hotspots). The number of stained vessels per in each hotspot was counted at high power fields $(\times 400)$. Any stained endothelia cell was considered as a countable single microvessel. Large vessels with thick muscular walls were excluded. MVD was classified as either low $(\leqq 35.0)$ or high ( $>35.0 /$ high power field (HPF)); 35.0 was the median value.

\section{Statistical analysis}

Statistical significance was evaluated by the chi-square test and Fisher exact test. Overall survival curves were analyzed by the Kaplan-Meier method, and differences between the curves were analyzed by log-rank test. The $p$ values smaller than 0.05 are regarded as significance.

\section{Results}

In Table 1, the mean age of the breast cancer patients was 46.5 years (range 19-73 years), and this was 44.6 years for controls (range 21-77 years). There was no significant difference between breast cancer patients and controls in age $(p=0.22)$.

In Figure 1A, RFLP results demonstrated that $\mathrm{CC}$ genotype yielded one band (76 base pairs), CT genotype yielded two bands (76 bp, C-allele; $153 \mathrm{bp}$, T allele) and TT genotype yielded one band (153 bp). The corresponding genotypes of homozygous and heterozygous patterns from
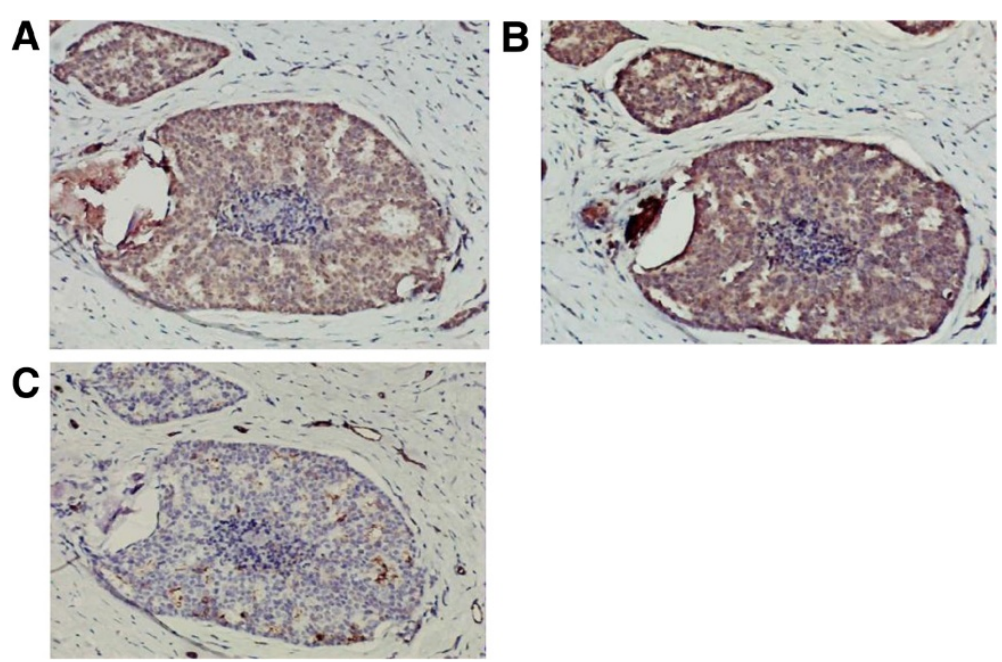

Figure 2 Expression of (A) HIF-1a, (B) VEGF and (C) CD34 for microvessel density (200x) of a 34 year-old female patient with T2N1M0 breast cancer. 
PCR-RFLP had confirmed by DNA sequence analysis (Figure 1B).

Based on PCR-RFLP analysis, the genotype distribution of control group was 116 CC (97\%), 0 CT (0\%) and 4. TT (3\%). In contrast, the genotype distributions of breast cancer patients were 53 CC (55\%), 21 CT (22\%), and $22 \mathrm{TT}$ (23\%). The genotype distribution in breast cancer patients differed significantly from that of controls $(p<0.001)$. The allele frequencies in controls and cancer patients were $232 \mathrm{C}(97 \%) / 8 \mathrm{~T}(3 \%)$ and $127 \mathrm{C}$ (66\%)/65 T (34\%), respectively. The $\mathrm{T}$-allele distribution in breast cancer patients differed significantly from that of controls $(p<0.001$, adjusted $O R=14.51)$.

Immunoreactivity of HIF-1 $\alpha$ was distributed in both nuclei and cytoplasm (Figure 2A). VEGF expression was measured by its cytoplasmic staining (Figure 2B). Microvessel density (MVD) representing tumor angiogenesis was measured by immunostaining of CD31 endothelial glycoprotein (Figure 2C).

When connecting the results of these stainings with HIF$1 \alpha$ genotypes with clinicopathological analysis (Table 2), there were no significant correlation between $1772 \mathrm{C}>\mathrm{T}$

Table 2 Clinicopathologic characteristics, clinical outcomes in breast cancer patients with different HIF-1a 1772 C > T genotypes

\begin{tabular}{|c|c|c|c|c|}
\hline Genotype & CC (\%) & CT (\%) & TT (\%) & $p$ value \\
\hline Case number & $53(55 \%)$ & $21(22 \%)$ & $22(23 \%)$ & \\
\hline Age & & & & $0.117^{a}$ \\
\hline Mean $\pm S D$ (years) & $46.5 \pm 9.7$ & $43.1 \pm 10.3$ & $49.4 \pm 9.6$ & \\
\hline Range (years) & $27 \sim 68$ & $19 \sim 62$ & $31 \sim 73$ & \\
\hline Laterality & & & & $0.463^{b}$ \\
\hline Left & $26(52 \%)$ & $10(20 \%)$ & $14(28 \%)$ & \\
\hline Right & $27(58 \%)$ & $11(24 \%)$ & $8(17 \%)$ & \\
\hline T-stage & & & & $0.303^{b}$ \\
\hline $\mathrm{T} 1$ or $\mathrm{T} 2$ & $35(53 \%)$ & $13(20 \%)$ & $18(27 \%)$ & \\
\hline $\mathrm{T} 3$ or T4 & $18(60 \%)$ & $8(27 \%)$ & $4(13 \%)$ & \\
\hline N-stage & & & & $0.936^{b}$ \\
\hline Node negative & $14(58 \%)$ & $5(21 \%)$ & $5(21 \%)$ & \\
\hline Node positive & 39 (54\%) & $16(22 \%)$ & 17 (24\%) & \\
\hline HIF-1a expression & & & & $0.311^{b}$ \\
\hline Low & $34(51 \%)$ & $15(22 \%)$ & $18(27 \%)$ & \\
\hline High & $19(66 \%)$ & $6(21 \%)$ & $4(14 \%)$ & \\
\hline VEGF expression & & & & $0.375^{b}$ \\
\hline Low & $18(62 \%)$ & $7(24 \%)$ & $4(14 \%)$ & \\
\hline High & 35 (52\%) & $14(21 \%)$ & $18(27 \%)$ & \\
\hline Microvessel density & & & & $0.211^{b}$ \\
\hline Low & $32(63 \%)$ & $8(16 \%)$ & $11(22 \%)$ & \\
\hline High & $21(47 \%)$ & 13 (29\%) & 11 (24\%) & \\
\hline
\end{tabular}

aby ANOVA test.

by Chi-Square test. genotypes (CC, CT and TT) of HIF- $1 \alpha$ gene and age ( $p=$ $0.117)$, T-stage $(p=0.303), \mathrm{N}$-stage $(p=0.936)$, local recurrence $(p=0.817)$, distant metastasis $(p=0.572)$, HIF- $1 \alpha$ expression $(p=0.311)$, VEGF expression $(p=0.375)$ and microvessel density $(p=0.211)$.

In Table 3, the multi-variable analyses in the determination of risk factors of disease-free survival and overall survival indicated that T-stage (Exp. (B) $=4.7270, p<$ $0.001)$ and microvessel density (Exp. $(\mathrm{B})=2.6082, p<0.05)$ were the most influential factors (Table 3). However, the SNP $1772 \mathrm{C}>\mathrm{T}$ genotypes of HIF-1 $\alpha$ gene were not correlated with the disease-free survival ( $p=0.35$, Cox regression) and overall survival ( $p=0.59$, Cox regression) by multi-variable analyses. Similarly, Kaplan-Meier analysis (Figures 3A and 3B) also showed a nonsignificant impact of $1772 \mathrm{C}>\mathrm{T}$ genotypes of HIF- $1 \alpha$ gene on disease-free survival ( $p=0.820$, Log-Rank test) and overall survival curves ( $p=0.963$, Log-Rank test), respectively.

\section{Discussion}

The SNP $1772 \mathrm{C}>\mathrm{T}$ of HIF-1 $\alpha$ gene chosen in current study are located within ODD of the HIF-1 $\alpha$. We found that T allele of the SNP $1772 \mathrm{C}>\mathrm{T}$ (P582S) of HIF-1 $\alpha$ gene was significantly higher in 96 breast cancer patients than in 120 controls. In contrast, the association results of SNP $1772 \mathrm{C}>\mathrm{T}$ of HIF-1 $\alpha$ gene with different kinds of cancers were not consistent in literature review. For

Table 3 Multivariate analysis of the risk factors on disease-free and overall survival in the 96 breast cancer patients

\begin{tabular}{|c|c|c|c|c|c|}
\hline Variable $^{a}$ & SE & $p$ value $^{b}$ & Exp. (B) & \multicolumn{2}{|c|}{$\begin{array}{l}95 \% \mathrm{Cl} \text { of } \\
\text { Exp. (B) }\end{array}$} \\
\hline \multicolumn{6}{|l|}{$\begin{array}{l}\text { Disease-free survival } \\
\text { time }\end{array}$} \\
\hline Age & 0.0253 & 0.1280 & 0.9622 & 0.9156 & $\sim 1.0112$ \\
\hline 1772 C > T genotype & 0.2715 & 0.3527 & 1.2871 & 0.7559 & $\sim 2.1913$ \\
\hline T-stage & 0.4033 & 0.0001 & 4.7270 & 2.1445 & $\sim 10.4196$ \\
\hline $\mathrm{N}$-stage & 0.5291 & 0.9816 & 1.0122 & 0.3588 & $\sim 2.8554$ \\
\hline Microvessel density & 0.4877 & 0.0493 & 2.6082 & 1.0028 & $\sim 6.7837$ \\
\hline VEGF expression & 0.5858 & 0.2901 & 1.8584 & 0.5895 & $\sim 5.8587$ \\
\hline HIF-1a expression & 0.4346 & 0.0732 & 2.1784 & 0.9294 & $\sim 5.1059$ \\
\hline \multicolumn{6}{|l|}{ Overall survival time } \\
\hline Age & 0.022 & 0.4883 & 0.9846 & 0.9422 & $\sim 1.0288$ \\
\hline 1772 C > T genotype & 0.300 & 0.5908 & 0.8508 & 0.4722 & $\sim 1.5330$ \\
\hline T-stage & 0.446 & 0.0017 & 4.0350 & 1.6850 & $\sim 9.6624$ \\
\hline $\mathrm{N}$-stage & 0.589 & 0.8594 & 1.1099 & 0.3502 & $\sim 3.5181$ \\
\hline Microvessel density & 0.646 & 0.0052 & 6.0924 & 1.7175 & $\sim 21.6115$ \\
\hline VEGF expression & 0.610 & 0.9791 & 0.9841 & 0.2979 & $\sim 3.2517$ \\
\hline HIF-1a expression & 0.481 & 0.3225 & 1.6094 & 0.6269 & $\sim 4.1315$ \\
\hline
\end{tabular}

${ }^{a}$ by Cox regression. SE, standard error; Exp. (B), exponent (B); $\mathrm{Cl}$, confidence interval. ${ }^{\mathrm{b}}$ Bold numbers indicate significance. 

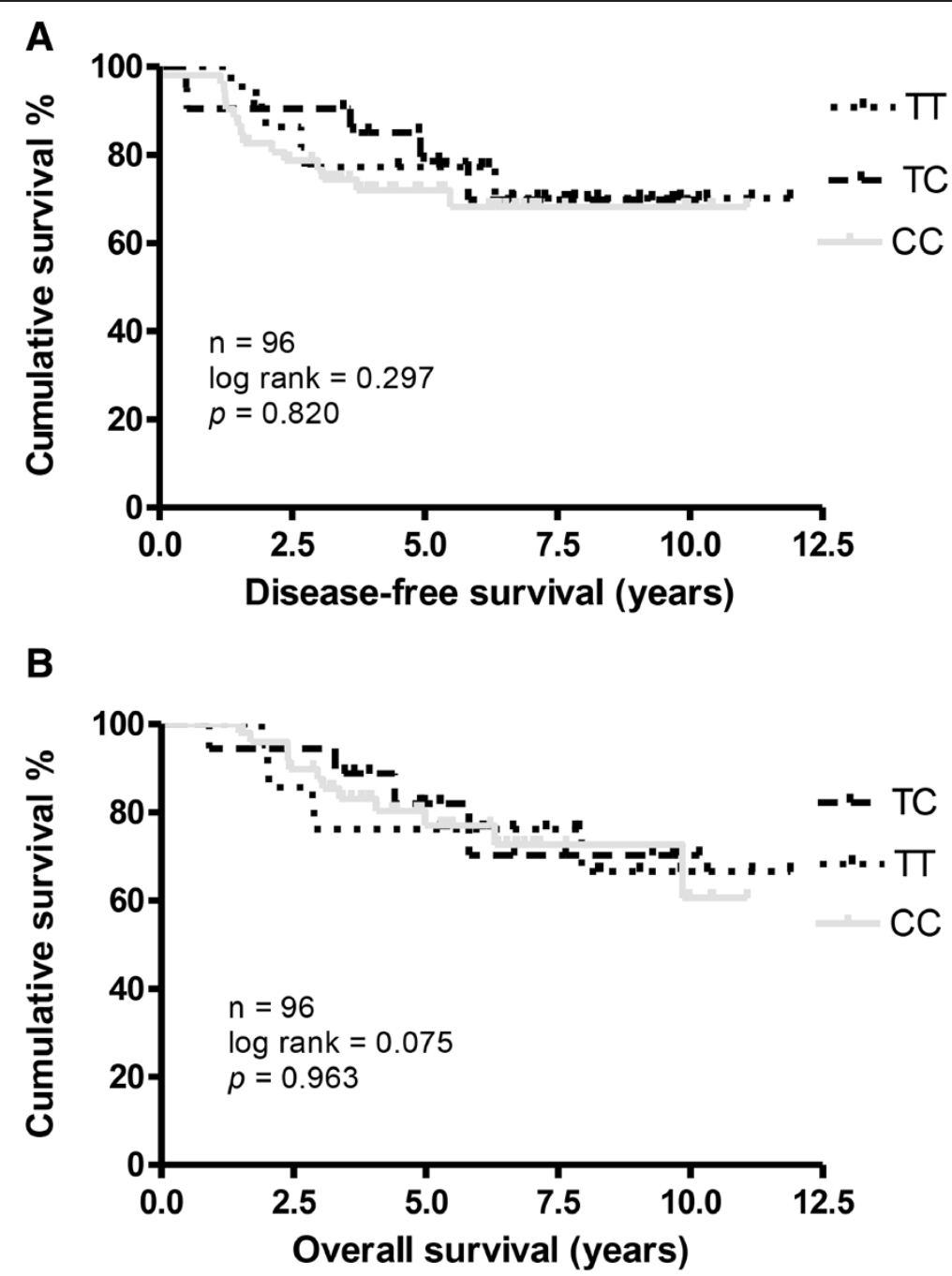

Figure 3 Kaplan-Meier disease-free and overall survival curves in breast cancer patients with different genotypes $(1772$ C $>$ T) of HIF-1a gene. (A) Disease-free survival. (B) overall survival curves.

example, the SNP $1772 \mathrm{C}>\mathrm{T}$ of HIF-1 $\alpha$ gene was detected in several cancers [18-21,23] but it was absent for colorectal [34], and cervical [35] cancers.

Within ODD of the HIF-1 $\alpha$, proline residues 402 and 564 were reported to independently determine tightly binding to the von Hippel-Lindau (VHL) protein for HIF- $1 \alpha$ ubiquitination and degradation under nonhypoxia condition [17,36-39]. In current study, however, the proline residue 582 located within ODD of the HIF$1 \alpha$, i.e., the SNP $1772 \mathrm{C}>\mathrm{T}$, was unable to interfere the binding of HIF- $1 \alpha$ with VHL and to impair HIF-1 $\alpha$ prolyl hydroxylation [40]. Similarly, the genotypes of SNP $1772 \mathrm{C}>\mathrm{T}$ of HIF-1 $\alpha$ gene did not show significant difference between low and high HIF-1 $\alpha$ levels in terms of immunostaining (Table 2). Other study [41] found that the HIF-1 $\alpha$ overexpressed in immunostaining measurement for invasive breast cancer in the absence of 1772
$\mathrm{C}>\mathrm{T}$ transition of HIF-1 $\alpha$ gene. Accordingly, the role of SNP $1772 \mathrm{C}>\mathrm{T}$ of HIF-1 $\alpha$ gene in its protein expression level is not clear. In future, the examination of more expression patterns of HIF- $1 \alpha$ protein in these patients may clearly investigate this relationship.

Furthermore, the genotypes of SNP $1772 \mathrm{C}>\mathrm{T}$ of HIF- $1 \alpha$ gene are not significantly associated with clinicopathologic characteristics and clinical outcome of breast cancer (Table 2) although SNP $1772 \mathrm{C}>\mathrm{T}$ of HIF-1 $\alpha$ gene confers significant association with breast cancer (Table 1). Similar results were reported in prostate cancer study [21]. Therefore, the SNP $1772 \mathrm{C}>\mathrm{T}$ of HIF-1 $\alpha$ gene is a good predictor for breast cancer risk but may be a poor clinicopathologic-associated factor.

The relationship between expression levels of HIF-1 $\alpha$ and survival of breast cancer patients has been investigated. For example, high levels of HIF-1 $\alpha$ were reportedly 
associated with decreased overall survival $(p=0.059)$ and disease-free survival $(p=0.110)$ [42]. Similarly, we found that HIF- $1 \alpha$ expression shows the association with disease-free survival $(p=0.0732)$ but weak association with overall survival $(p=0.3225)$ (Table 3$)$. These results suggest that expression levels of HIF-1 $\alpha$ may be the potential risk factor for survival prediction of breast cancer.

The phenomena mentioned above may be partly explained by the multigene theory for carcinogenesis [43]. Furthermore, many SNPs may be associated with breast cancer. Although only single SNP was examined in our study, the SNP-SNP interaction [9,44-48] tumor may play a joint effect to associate with cancer and it is warranted for further investigation for multiple SNPs in breast cancer association.

\section{Conclusion}

Taken together, SNP 1772 C > T (P582S) of HIF-1 $\alpha$ gene confers significant association with breast cancer risk but it show no association with the clinicopathologic features and survival of breast cancer patients.

\section{Competing interests}

The authors have no conflict of interests to declare.

\section{Authors' contributions}

C-JH and H-WC managed for genotyping studies. C-JH and S-LL drafted the manuscript. M-FH and C-YC were responsible for the sample collection and pathology experiments. Y-HY performed statistics analyses. S-FL and H-WC were involved in discussion and editing the manuscript. All authors read and approved the final manuscript.

\section{Acknowledgement}

This work was supported by grants from the National Science Council (NSC92-2314-B-037-051, NSC102-2622-B-037-003-CC2, and MOST 103-2320-B037-008), the KMU Cancer Research Foundation (QC094002), the National Sun Yat-Sen University-KMU Joint Research Project (\#NSYSU-KMU 103-p014), and Health and welfare surcharge of tobacco products, the Ministry of Health and Welfare, Taiwan, Republic of China (MOHW103-TD-B-111-05). We thank Sung-Wei Li, MD, for clinical data collection; De-Leung Gu in technical assistance of RFLP; Wen-Tsue Chen in immunohistochemistry stain; and Susan L. Olmstead, Ph.D., Johns Hopkins University for English revision.

\section{Author details}

${ }^{1}$ Graduate Institute of Medicine, College of Medicine, Kaohsiung Medical University Faculty of medicine, Kaohsiung Medical University, Kaohsiung, Taiwan. ${ }^{2}$ Department of Radiation Oncology, Kaohsiung Medical University Hospital, Kaohsiung, Taiwan. ${ }^{3}$ Institute of Clinical Medicine, Kaohsiung Medical University, Kaohsiung, Taiwan. ${ }^{4}$ Kaohsiung Municipal Ta-Tung Hospital, Kaohsiung, Taiwan. ${ }^{5}$ Cancer Center, Kaohsiung Medical University Hospital, Kaohsiung Medical University, Kaohsiung, Taiwan. ${ }^{6}$ Department of Pathology, Kaohsiung Medical University Hospital, Kaohsiung Medical University, Kaohsiung, Taiwan. ${ }^{7}$ Institute of Biomedical Sciences, National Sun Yat-Sen University, Kaohsiung, Taiwan. ${ }^{8}$ Department of Pathology, Kaohsiung Medical University Hospital, Kaohsiung Medical University, Kaohsiung, Taiwan. ${ }^{9}$ School of Pharmacy, Kaohsiung Medical University, Kaohsiung, Taiwan. ${ }^{10}$ Department of Medical Oncology, Kaohsiung Medical University Hospital, Kaohsiung Medical University, Kaohsiung, Taiwan. ${ }^{11}$ Translational Research Center, Kaohsiung Medical University Hospital, Kaohsiung Medical University, Kaohsiung, Taiwan. ${ }^{12}$ Institute of Medical Science and Technology, National Sun Yat-sen University, Kaohsiung, Taiwan. ${ }^{13}$ Department of Biomedical Science and Environmental Biology, Kaohsiung Medical University, Kaohsiung, Taiwan.
Received: 13 April 2014 Accepted: 25 August 2014

Published online: 26 September 2014

\section{References}

1. Chuang LY, Yang $\mathrm{CH}$, Tsui $\mathrm{KH}$, Cheng YH, Chang PL, Wen $\mathrm{CH}$, Chang HW: Restriction enzyme mining for SNPs in genomes. Anticancer Res 2008, 28(4A):2001-2007.

2. Cantor CR: The use of genetic SNPs as new diagnostic markers in preventive medicine. Ann N Y Acad Sci 2005, 1055:48-57.

3. Chang HW, Chuang LY, Tsai MT, Yang CH: The importance of integrating SNP and cheminformatics resources to pharmacogenomics. Curr Drug Metab 2012, 13(7):991-999.

4. Liu SG, Gao C, Zhang RD, Jiao Y, Cui L, Li WJ, Chen ZP, Wu MY, Zheng HY, Zhao XX, Yue ZX, Li ZG: FPGS rs1544105 polymorphism is associated with treatment outcome in pediatric B-cell precursor acute lymphoblastic leukemia. Cancer Cell Int 2013, 13(1):107.

5. Ding $H$, Jing $X$, Ding N, Fu Z, Song $Y$, Zhu J: Single nucleotide polymorphisms of $C D 20$ gene and their relationship with clinical efficacy of R-CHOP in patients with diffuse large B cell lymphoma. Cancer Cell Int 2013, 13(1):58

6. Lin HJ, Kung YJ, Lin YJ, Sheu JJ, Chen BH, Lan YC, Lai CH, Hsu YA, Wan L, Tsai FJ: Association of the lumican gene functional 3'-UTR polymorphism with high myopia. Invest Ophthalmol Vis Sci 2010, 51(1):96-102.

7. Kuo HC, Yang KD, Juo SH, Liang CD, Chen WC, Wang YS, Lee $\mathrm{CH}$, Hsi E, Yu HR, Woon PY, Lin IC, Huang CF, Hwang DY, Lee CP, Lin LY, Chang WP, Chang WC: ITPKC single nucleotide polymorphism associated with the Kawasaki disease in a Taiwanese population. PLoS One 2011, 6(4):e17370.

8. Hwang CW, Lu CH, Sun SF, Sung TY, Chung HY, Huang SY, Hung HC, Chen $\mathrm{CH}$, Sun YM, Lin YY, Liu WS, Wen ZH: Comprehensive association analysis of 10 single nucleotide polymorphisms associated with osteoporosis among a Taiwanese population. Int J Hum Genet 2011, 11(4):249-257.

9. Lin GT, Tseng HF, Yang CH, Hou MF, Chuang LY, Tai HT, Tai MH, Cheng YH, Wen CH, Liu CS, Huang CJ, Wang CL, Chang HW: Combinational polymorphisms of seven CXCL12-related genes are protective against breast cancer in Taiwan. OMICS 2009, 13(2):165-172.

10. Chen FM, Ou-Yang F, Yang SF, Tsai EM, Hou MF: P53 codon 72 polymorphism in Taiwanese breast cancer patients. Kaohsiung J Med SC 2013, 29(5):259-264

11. Chang WC, Woon PY, Hsu YW, Yang S, Chiu YC, Hou MF: The association between single-nucleotide polymorphisms of ORAI1 gene and breast cancer in a Taiwanese population. ScientificWorldJournal 2012, 2012:916587.

12. Semenza GL: Targeting HIF-1 for cancer therapy. Nat Rev Cancer 2003, 3(10):721-732

13. Bos $R$, Zhong H, Hanrahan CF, Mommers EC, Semenza GL, Pinedo HM, Abeloff MD, Simons JW, van Diest PJ, van der Wall E: Levels of hypoxia-inducible factor-1 alpha during breast carcinogenesis. J Nat/ Cancer Inst 2001, 93(4):309-314

14. Gruber G, Greiner RH, Hlushchuk R, Aebersold DM, Altermatt HJ, Berclaz G, Djonov V: Hypoxia-inducible factor 1 alpha in high-risk breast cancer: an independent prognostic parameter? Breast Cancer Res 2004, 6(3):R191-R198.

15. Semenza GL: HIF-1: mediator of physiological and pathophysiological responses to hypoxia. J App/ Physio/ 2000, 88(4):1474-1480.

16. Epstein AC, Gleadle JM, MCNeill LA, Hewitson KS, O'Rourke J, Mole DR, Mukherji M, Metzen E, Wilson MI, Dhanda A, Tian YM, Masson N, Hamilton DL, Jaakkola P, Barstead R, Hodgkin J, Maxwell PH, Pugh CW, Schofield CJ, Ratcliffe PJ: C. elegans EGL-9 and mammalian homologs define a family of dioxygenases that regulate HIF by prolyl hydroxylation. Cell 2001, 107(1):43-54

17. Jaakkola P, Mole DR, Tian YM, Wilson MI, Gielbert J, Gaskell SJ, Kriegsheim A, Hebestreit HF, Mukherji M, Schofield CJ, Maxwell PH, Pugh CW, Ratcliffe PJ: Targeting of HIF-alpha to the von Hippel-Lindau ubiquitylation complex by O2-regulated prolyl hydroxylation. Science 2001, 292(5516):468-472.

18. Ollerenshaw M, Page T, Hammonds J, Demaine A: Polymorphisms in the hypoxia inducible factor-1alpha gene (HIF1A) are associated with the renal cell carcinoma phenotype. Cancer Genet Cytogenet 2004, 153(2):122-126.

19. Clifford SC, Astuti D, Hooper L, Maxwell PH, Ratcliffe PJ, Maher ER: The pVHL-associated SCF ubiquitin ligase complex: molecular genetic 
analysis of elongin B and C, Rbx1 and HIF-1alpha in renal cell carcinoma. Oncogene 2001, 20(36):5067-5074.

20. Tanimoto K, Yoshiga K, Eguchi H, Kaneyasu M, Ukon K, Kumazaki T, Oue N, Yasui W, Imai K, Nakachi K, Poellinger L, Nishiyama M: Hypoxia-inducible factor-1alpha polymorphisms associated with enhanced transactivation capacity, implying clinical significance. Carcinogenesis 2003, 24(11):1779-1783.

21. Orr-Urtreger A, Bar-Shira A, Matzkin H, Mabjeesh NJ: The homozygous P582S mutation in the oxygen-dependent degradation domain of HIF-1 alpha is associated with increased risk for prostate cancer. Prostate 2007, 67(1):8-13

22. Kuo WH, Shih CM, Lin CW, Cheng WE, Chen SC, Chen W, Lee YL: Association of hypoxia inducible factor-1alpha polymorphisms with susceptibility to non-small-cell lung cancer. Trans/ Res 2012, 159(1):42-50.

23. Ruiz-Tovar J, Fernandez-Contreras ME, Martin-Perez E, Gamallo C: Association of thymidylate synthase and hypoxia inducible factor-1alpha DNA polymorphisms with pancreatic cancer. Tumori 2012, 98(3):364-369.

24. Yang X, Zhu HC, Zhang C, Qin Q, Liu J, Xu LP, Zhao LJ, Zhang Q, Cai J, Ma JX, Cheng HY, Sun XC: HIF-1alpha 1772 C/T and $1790 \mathrm{G} / \mathrm{A}$ polymorphisms are significantly associated with higher cancer risk: an updated meta-analysis from 34 case-control studies. PLoS One 2013, 8(11):e80396.

25. Prchal JT: Delivery on demand-a new era of gene therapy? N Engl J Med 2003, 348(13):1282-1283.

26. Huang CJ, Hou MF, Lin SD, Chuang HY, Huang MY, Fu OY, Lian SL Comparison of local recurrence and distant metastases between breast cancer patients after postmastectomy radiotherapy with and without immediate TRAM flap reconstruction. Plast Reconstr Surg 2006, 118(5):1079-1086. discussion 1087-1078.

27. Singer G, Kurman RJ, Chang HW, Cho SK, Shih le M: Diverse tumorigenic pathways in ovarian serous carcinoma. Am J Pathol 2002, 160(4):1223-1228.

28. Chang HW, Cheng CA, Gu DL, Chang CC, Su SH, Wen CH, Chou YC, Chou TC, Yao CT, Tsai CL, Cheng CC: High-throughput avian molecular sexing by SYBR green-based real-time PCR combined with melting curve analysis. BMC Biotechnol 2008, 8:12.

29. Chang HW, Cheng YH, Chuang LY, Yang CH: SNP-RFLPing 2: an updated and integrated PCR-RFLP tool for SNP genotyping. BMC Bioinformatics 2010, 11:173.

30. Chang HW, Yang CH, Chang PL, Cheng YH, Chuang LY: SNP-RFLPing: restriction enzyme mining for SNPs in genomes. BMC Genomics 2006, 7(1):30.

31. Yang $\mathrm{CH}$, Cheng $Y H$, Chuang $L Y$, Chang HW: Drug-SNPing: an integrated drug-based, protein interaction-based tagSNP-based pharmacogenomics platform for SNP genotyping. Bioinformatics 2013, 29(6):758-764.

32. Chen WT, Huang CJ, Wu MT, Yang SF, Su YC, Chai CY: Hypoxia-inducible factor-1alpha is associated with risk of aggressive behavior and tumor angiogenesis in gastrointestinal stromal tumor. Jpn J Clin Oncol 2005, 35(4):207-213

33. Zhong $H$, De Marzo AM, Laughner E, Lim M, Hilton DA, Zagzag D, Buechler $P$, Isaacs WB, Semenza GL, Simons JW: Overexpression of hypoxia-inducible factor 1alpha in common human cancers and their metastases. Cancer Res 1999, 59(22):5830-5835.

34. Kuwai T, Kitadai Y, Tanaka S, Kuroda T, Ochiumi T, Matsumura S, Oue N, Yasui W, Kaneyasu M, Tanimoto K, Nishiyama M, Chayama K: Single nucleotide polymorphism in the hypoxia-inducible factor-1alpha gene in colorectal carcinoma. Oncol Rep 2004, 12(5):1033-1037.

35. Fu SL, Miao J, Ding B, Wang XL, Cheng WJ, Dai HH, Han SP: A polymorphism in the $3^{\prime}$ untranslated region of Hypoxia-Inducible Factor-1 alpha confers an increased risk of cervical cancer in a Chinese population. Neoplasma 2014, 61(1):63-69.

36. Salceda S, Caro J: Hypoxia-inducible factor 1alpha (HIF-1alpha) protein is rapidly degraded by the ubiquitin-proteasome system under normoxic conditions. Its stabilization by hypoxia depends on redox-induced changes. J Biol Chem 1997, 272(36):22642-22647.

37. Maxwell PH, Wiesener MS, Chang GW, Clifford SC, Vaux EC, Cockman ME, Wykoff CC, Pugh CW, Maher ER, Ratcliffe PJ: The tumour suppressor protein VHL targets hypoxia-inducible factors for oxygen-dependent proteolysis. Nature 1999, 399(6733):271-275.

38. Masson N, Willam C, Maxwell PH, Pugh CW, Ratcliffe PJ: Independent function of two destruction domains in hypoxia-inducible factor-alpha chains activated by prolyl hydroxylation. Embo J 2001, 20(18):5197-5206.
39. Min JH, Yang H, Ivan M, Gertler F, Kaelin WG Jr, Pavletich NP: Structure of an HIF-1alpha -pVHL complex: hydroxyproline recognition in signaling. Science 2002, 296(5574):1886-1889.

40. Percy MJ, Mooney SM, McMullin MF, Flores A, Lappin TR, Lee FS: A common polymorphism in the oxygen-dependent degradation (ODD) domain of hypoxia inducible factor-1alpha (HIF-1alpha) does not impair Pro-564 hydroxylation. Mol Cancer 2003, 2:31.

41. Vleugel MM, Greijer $A E$, van der Wall E, van Diest PJ: Mutation analysis of the HIF-1alpha oxygen-dependent degradation domain in invasive breast cancer. Cancer Genet Cytogenet 2005, 163(2):168-172.

42. Bos R, van der Groep P, Greijer AE, Shvarts A, Meijer S, Pinedo HM, Semenza GL, van Diest PJ, van der Wall E: Levels of hypoxia-inducible factor-1alpha independently predict prognosis in patients with lymph node negative breast carcinoma. Cancer 2003, 97(6):1573-1581

43. Goncalves R, Bose R: Using multigene tests to select treatment for early-stage breast cancer. J Natl Compr Canc Netw 2013, 11(2):174-182. quiz 182.

44. Yang $\mathrm{CH}$, Chuang LY, Cheng $\mathrm{YH}$, Lin YD, Wang $\mathrm{CL}$, Wen $\mathrm{CH}$, Chang $\mathrm{HW}$ : Single nucleotide polymorphism barcoding to evaluate oral cancer risk using odds ratio-based genetic algorithms. Kaohsiung J Med Sci 2012, 28(7):362-368.

45. Yen $C Y$, Liu SY, Chen $C H$, Tseng HF, Chuang LY, Yang CH, Lin YC, Wen $C H$, Chiang WF, Ho CH, Chen HC, Wang ST, Lin CW, Chang HW: Combinational polymorphisms of four DNA repair genes XRCC1, XRCC2, XRCC3, and XRCC4 and their association with oral cancer in Taiwan. $J$ Oral Pathol Med 2008, 37(5):271-277.

46. Zheng SL, Sun J, Wiklund F, Smith S, Stattin P, Li G, Adami HO, Hsu FC, Zhu Y, Balter K, Kader AK, Turner AR, Liu W, Bleecker ER, Meyers DA, Duggan D, Carpten JD, Chang BL, Isaacs WB, Xu J, Gronberg H: Cumulative association of five genetic variants with prostate cancer. $N$ Engl J Med 2008, 358(9):910-919.

47. Vogelsang M, Wang Y, Veber N, Mwapagha LM, Parker MI: The cumulative effects of polymorphisms in the DNA mismatch repair genes and tobacco smoking in oesophageal cancer risk. PLoS One 2012, 7(5):e36962.

48. Chang WC, Fang YY, Chang HW, Chuang LY, Lin YD, Hou MF, Yang CH: Identifying association model for single-nucleotide polymorphisms of ORAl1 gene for breast cancer. Cancer Cell Int 2014, 14(1):29.

doi:10.1186/s12935-014-0087-7

Cite this article as: Huang et al.: SNP 1772 C > T of HIF-1a gene associates with breast cancer risk in a Taiwanese population. Cancer Cell International 2014 14:87.

\section{Submit your next manuscript to BioMed Central and take full advantage of:}

- Convenient online submission

- Thorough peer review

- No space constraints or color figure charges

- Immediate publication on acceptance

- Inclusion in PubMed, CAS, Scopus and Google Scholar

- Research which is freely available for redistribution 